\title{
EVALUASI STATUS MUTU AIR DANAU RAWAPENING
}

\section{The Assessment of Rawapening Lake Water Quality Status}

\author{
Agatha Sih Pirantia ${ }^{\mathrm{a}}$ Diana Rus Rahayu ${ }^{\mathrm{a}}$, Gentur Waluyo ${ }^{\mathrm{b}}$ \\ ${ }^{a}$ Bagian Biologi Lingkungan, Fakultas Biologi Unsoed, Kampus Grendeng Purwokerto, Jawa Tengah \\ - agatha.piranti@gmail.com \\ ${ }^{b}$ Jurusan Geologi Lingkungan, Fakultas Teknik Unsoed Purwokerto, Kampus Blater Purbalingga, Jawa Tengah.
}

\begin{abstract}
Increasing type and number of human activities will impact on decreasing quality of water. Therefore, it is necessary to determine the water quality status of Rawapening Lake regularly to ensure that the water quality remains in its natural condition. The purposes of this study were to evaluate the water quality status and class of Rawapening Lake. The survey was done in the lake during dry season for 3 months (July to September 2016). Water sampling conducted in seven locations. The measured variables were all parameters as specified in Government Regulation No. 82 of 2001. To determine the water quality status was using storet methods. Determination of the water class was by comparing the concentration of all parameters with the standard. Observations indicated that the Rawapening Lake water quality status was in heavily polluted. There were eight parameters exceeding the standard i.e. TSS, BOD, COD, total phosphor and total coliform, $\mathrm{Cd}$ and $\mathrm{Pb}$, and $\mathrm{H}_{2} \mathrm{~S}$. Therefore, it is necessary to decrease them through activities such as not throwing rubbish into the lake, lifting biomass of water hyacinth, picking up peat soil sediments, using environmentally friendly fuels, reducing fertilizers and pellet, reforesting critical lands, limiting mining activities, banning waste disposal directly to rivers.
\end{abstract}

Keywords: Rawapening Lake, water quality standard, STORET index

(Diterima: 04-03-2017; Disetujui: 22-09-2017)

\section{Pendahuluan}

Danau Rawapening, merupakan danau alami yang berada di Kabupaten Semarang, yang berfungsi untuk menahan laju dan menampung aliran air permukaan yang kemudiaan dimanfaatkan untuk berbagai kepentingan masyarakat. Kementrian Lingkungan Hidup (2011) menyatakan bahwa manfaat Danau Rawapening tersebut adalah untuk: 1) supply air untuk PLTA Jelok yang merupakan bagian dari interkoneksi listrik Jawa Bali, 2) Irigasi pertanian bagi sawah di Kabupaten Semarang, Kabupaten Demak dan Kabupaten Grobogan, 3) Pengendali banjir daerah hilir terutama di Kabupaten Demak dan Kabupaten Grobogan, 4) Kegiatan pariwisata, 5) Kegiatan perikanan darat baik perikanan alami maupun perikanan budidaya, 6) Penyedia air baku dan air untuk industry, 7) Persawahan pasang surut, 8) bahan baku Handicraft dari eceng gondok, 9) Penambangan gambut sebagai bahan dasar pupuk organik dan sarana budidaya jamur. Mulai tahun 2015, Danau Rawapening juga dimanfaatkan sebagai sumber air baku air minum oleh Perusahaan Daerah Air Minum (PDAM) untuk memenuhi kekurangan air baku PDAM kabupaten Semarang (Peraturan Gubernur Jawa Tengah Nomor 5 Tahun 2014 Tentang Peruntukan Air Dan Pengelolaan Kualitas Air Sungai Tuntang Di Provinsi Jawa Tengah). Air baku diambil dari Kanal Sungai Tuntang yang berada di area outlet Danau Rawapening.

Dengan berbagai peruntukannya tersebut maka Danau Rawapening ditetapkan sebagai salah satu danau prioritas nasional Indonesia karena keberadaannya memberikan nilai manfaat cukup strategis, namun 151 mengalami permasalahan ekosistem yang sangat serius dan harus segera ditangani. Ada 3 permasalahan yang menjadi penyebab kerusakan ekosistem Danau Rawapening yaitu kerusakan daerah tangkapan air, kerusakan sempadan danau, dan pencemaran air (KLH, 2011).

Luas Daerah Tangkapan Air (DTA) Danau Rawapening sebesar 27,345.98 hektar dan kondisinya telah mengalami degradasi yang disebabkan oleh alih fungsi lahan dari lahan hutan (tegakan) menjadi lahan pertanian. Alih fungsi lahan ini cenderung meluas pada lereng curam $25-40 \%$ hingga sangat curam $>40 \%$ (Apriliyana, 2015). Hal ini mengakibatkan meningkatkan laju erosi dan sedimentasi di Danau Rawapening. Adanya penambangan galian andesit dan sirtu juga menjadi penyebab munculnya permasalahan tanah longsor sehingga kerentanan lahan terhadap tanah longsor termasuk dalam kategori "tinggi" sehingga masuk dalam kategori cukup membahayakan bagi kelestarian danau Rawa Pening (Paimin et al., 2012). Kondisi DTA dengan tata guna lahan tersebut diikuti dengan meningkatnya aktifitas baik di danau maupun di DTA seperti kegiatan domestic, pertanian dan industry akan memberikan dampak terhadap kualitas air danau Nurmalita et al. (2013). Daerah sempadan danau yang seharusnya merupakan daerah lahan pasang surut dan seharusnya sebagai daerah konservasi telah dimanfaatkan untuk lahan pertanian. Kegiatan manusia di perairan danau seperti budidaya ikan menggunakan karamba, perikanan tangkap, pariwisata, pengambilan tanah gambut, serta berbagai aktifitas seperti limbah rumah tangga, sisa-sisa makanan ikan, sisa-sisa aktifitas pertanian, industri dan doi: $10.29244 / j p s 1.8 .2 .151-160$ 
erosi akan menyebabkan penurunan kualitas air yang apabila tidak ditanggulangi akan menyebabkan kerusakan ekosistem danau.

Dengan berbagai macam fungsi yang bersifat sangat strategis tersebut, namun di pihak lain berdampak menimbulkan permasalahan ekosistem yang sangat kompleks maka untuk memastikan bahwa kualitas airnya tetap berada pada kondisi alamiahnya, maka kualitas air Danau Rawapening harus selalu dipantau. Selama ini pemantauan kualitas air telah dilakukan namun hanya bersifat sesaat dan pengukuran parameter dilakukan hanya bersifat onsite sehingga tidak menggambarkan kondisi kualitas air danau secara holistik atau dalam skala ekosistem. Pada kajian ini akan dilakukan evaluasi status mutu untuk menentukan kelas air danau Rawapening dengan melakukan pengukuran parameter pada musim kemarau ketika suplai air ke danau minimal sehingga dapat diperoleh gambaran status mutu air Danau Rawapening pada saat musim kemarau ketika terjadi tingkat pencemaran terparah karena tidak ada pengenceran oleh air hujan.

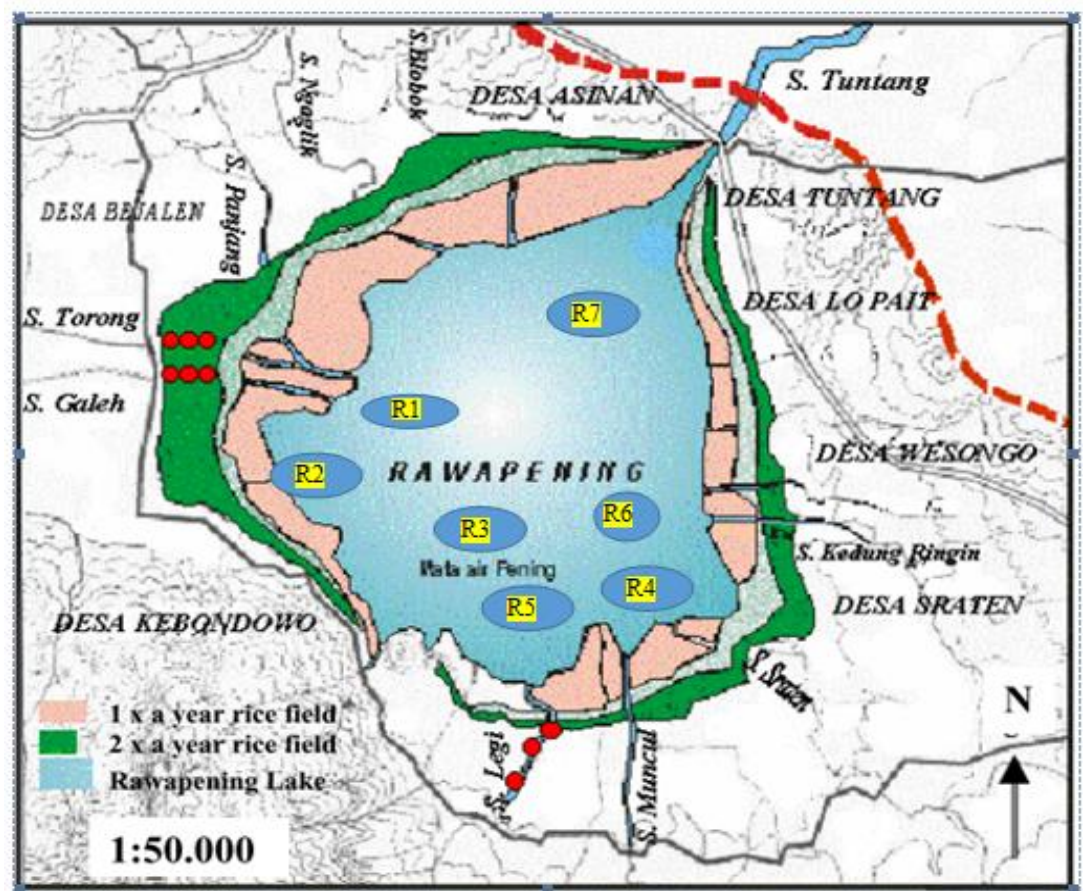

Keterangan:

R1. Daerah muara sungai Torong dan Galeh,

R2. Daerah bukit cinta dan daerah TPI,

R3. Daerah mata air,

R4. Daerah muara Sungai Sraten,

R5. Daerah muara Sungai Legi Dan Muncul,

R6. Daerah muara Sungai Kedungringin,

R7. Daerah outlet (air keluar) Sungai Tuntang.

Gambar 1. Lokasi Pengambilan Sampel Air di Perairan Danau Rawa Pening (Sumber Peta: BPPD Jawa Tengah, 2000)

Variabel yang diukur adalah konsentrasi semua parameter kualitas air seperti yang tercantum pada Peraturan Pemerintah Nomor 82 Tahun 2001.

\subsection{Jenis dan Sumber Data}

Data yang digunakan bersumber dari data primer hasil pengukuran konsentrasi parameter kualitas air yang dipersyaratkan sesuai dengan kelas airnya. Data yang diambil meliputi data fisik (suhu, residu terlarut dan tersuspensi), kimia (kimia an organik dan organik), Mikrobiologi (Total Coliform dan Fecal Coliform, dan radioaktifitas. Pengambilan data dilakukan selama musim kemarau sebanyak 3 kali selama 3 bulan (Juli,
Agustus, dan September 2016) dengan interval waktu pengambilan sebulan sekali.

\subsection{Metode Pengumpulan Data}

Data yang diperoleh berupa data pengukuran parameter in situ (suhu, $\mathrm{pH}$, oksigen terlarut), dan data yang diperoleh melalui uji laboratorium untuk parameter-parameter yang tercantum pada PP nomor 82 Tahun 2001 dari masing-masing sampel yang diambil dari masing-masing stasiun pengambilan sampel. Pengambilan sampel air dari masing-masing stasiun dilakukan pada siang hari dari jam $10.00-$ 13.00 WIB menggunakan water sampler pada permukaan perairan (kedalaman $20 \mathrm{~cm}$ ) sebanyak 2 
liter dan ditempatkan pada botol sampel. Botol sampel ini disegel dan ditempatkan di lingkungan yang gelap pada kisaran suhu konstan $4-10^{\circ} \mathrm{C}$ untuk menghindari kontaminasi dan dampak cahaya dan suhu. Sampel air dari lapangan dianalisis di laboratorium untuk ditentukan konsentrasinya berdasarkan APHA (1992) dan ditabulasi sebelum dilakukan analisis data.

\subsection{Analisis Data}

\section{a. Status Mutu air}

Untuk menentukan status mutu air Danau Rawapening dilakukan dengan menggunakan metode STORET (Esta et al., 2016). Data hasil pengukuran masing-masing parameter kualitas air yang meliputi nilai minimum, nilai maksimum dan nilai rata-rata berdasarkan 3 kali pengukuran selama 3 bulan tersebut digunakan sebagai dasar perhitungan indeks STORET yang dikeluarkan oleh EPA (Environmental Protection Agency) yang mengklasifikasikan mutu air ke dalam empat kelas, yaitu:

(1) Kelas A: baik sekali, skor=0 memenuhi baku mutu

(2) Kelas B: baik, skor $=-1 \mathrm{~s} / \mathrm{d}-10$ cemar ringan

(3) Kelas C: sedang, skor $=-11 \mathrm{~s} / \mathrm{d}-30$ cemar sedang

(4) Kelas D: buruk, skor > -31 cemar berat.

Penentuan status mutu air dengan menggunakan metode STORET ini dilakukan dengan langkahlangkah sebagai berikut:

1. membandingkan data hasil pengukuran dari masing-masing parameter air dengan nilai baku mutu yang sesuai dengan kelas air;

2. jika hasil pengukuran memenuhi nilai baku mutu (hasil pengukuran < baku mutu) maka diberi skor 0 ,

3. jika hasil pengukuran tidak memenuhi baku mutu air (hasil pengukuran > baku mutu) maka diberi skor sesuai kelompok parameter dan jumlah data seperti pada Tabel 1.

Tabel 1. Penentuan Sistem Nilai Untuk Menentukan Status Mutu Air.

\begin{tabular}{llccc}
\hline \multirow{2}{*}{ Jumlah contoh } & \multirow{2}{*}{ Nilai } & \multicolumn{3}{c}{ Parameter } \\
\cline { 3 - 5 } & & Fisika & Kimia & Biologi \\
\hline$<10$ & maksimum & -1 & -2 & -3 \\
& minimum & -1 & -2 & -3 \\
& Rata-rata & -3 & -6 & -9 \\
\hline$>10$ & maksimum & -2 & -4 & -6 \\
& minimum & -2 & -4 & -6 \\
& Rata-rata & -6 & -12 & -18 \\
\hline
\end{tabular}

\section{b. Kelas air}

Penentuan kelas air dilakukan dengan membandingkan konsentrasi semua parameter kualitas air seperti yang tercantum dalam PP Nomor 82 Tahun 2001 dibandingkan dengan baku mutu air Kelas I, Kelas II, Kelas III dan Kelas IV untuk setiap parameter tersebut. Klasifikasi mutu air ditetapkan menjadi 4 (empat) kelas:

a. Kelas I, air yang peruntukannya dapat digunakan untuk air baku air minum, dan atau peruntukan lain yang mempersyaratkan mutu air yang sama dengan kegunaan tersebut; b. Kelas II, air yang peruntukannya dapat digunakan untuk prasarana/sarana rekreasi air, pembudidayaan ikan air tawar, peternakan, air untuk mengairi pertanaman, dan atau peruntukan lain yang mempersyaratkan mutu air yang sama dengan kegunaan tersebut;

c. Kelas III, air yang peruntukannya dapat digunakan untuk pembudidayaan ikan air tawar, peternakan, air untuk mengairi pertanaman, dan atau peruntukan lain yang mempersyaratkan air yang sama dengan kegunaan tersebut;

d. Kelas IV, air yang peruntukannya dapat digunakan untuk mengairi pertanaman dan atau peruntukan lain yang mempersyaratkan mutu air yang sama dengan kegunaan tersebut.

\section{Hasil dan Pembahasan}

\section{a. Satus Mutu Air}

Tingkat pencemaran perairan didasarkan pada banyaknya unsur polutan yang terkandung dalam perairan tersebut dan ditetapkan sebagai nilai baku mutu air (BMA). Apabila jumlah polutan telah melebihi baku mutu yang ditetapkan artinya keberadaannya telah dapat menyebabkan kerugian terhadap makhluk hidup yang memanfaatkan perairan tersebut.

Status mutu air Danau Rawapening pada saat dilakukan observasi apabila dibandingkan dengan BMA Kelas I dan II menunjukkan bahwa di semua stasiun kondisinya tercemar berat, namun apabila dibandingkan dengan BMA kelas 3, stasiun pengamatan (R1, R2, R5, R6, R7) kondisinya tercemar sedang, hanya di stasiun R3 dan R4 yang berada pada kondisi tercemar berat (Tabel 2).

Hal ini menunjukkan bahwa air Danau Rawapening tidak sesuai apabila dimanfaatkan sesuai peruntukan air kelas 1 dan 2 yaitu sebagai sumber baku air minum dan sarana rekreasi air. Air Danau Rawapening hanya layak digunakan untuk peruntukan air Kelas III dan IV yaitu untuk budidaya perikanan dan mengairi pertamanan/irigasi.

Berdasarkan hasil pemantauan yang dilakukan pada saat penelitian menunjukkan bahwa ada 8 parameter yang melebihi baku mutu air baik Kelas I, II, maupun kelas III yaitu TSS, Total P, BOD, COD, Total Coliform, Logam $\mathrm{Cd}, \mathrm{Pb}$ dan $\mathrm{H}_{2} \mathrm{~S}$ (Tabel 3).

Konsentrasi Total suspended solid (TSS) di semua lokasi sampling sudah sangat tinggi yaitu berkisar $140.87-242.100$ mg..$^{-1}$. Konsentrasi TSS di semua lokasi telah melebihi baku mutu Air (BMA) kelas I dan II, namun masih jauh di bawah BMA kelas III dan IV (Gambar 1). Hal ini menunjukkan bahwa berdasarkan konsentrasi TSS Danau Rawapening masih sesuai apabila dapat digunakan untuk kepentingan budidaya air dan mengairi pertamanan (Kelas III dan IV), namun tidak sesuai untuk kebutuhan air baku air minum dan rekreasi air (kelas I dan II).

Total suspended solid (TSS) adalah bahan-bahan tersuspensi (diameter $>1 \mu \mathrm{m}$ ) yang tertahan pada 
saringan milli -pore dengan diameter pori-pori $0,45 \mu \mathrm{m}$. TSS terdiri atas lumpur dan pasir halus serta jasad-jasad renik, yang terutama disebabkan oleh kikisan tanah atau erosi tanah yang terbawa ke badan air (Effendi, 2003).

Tabel 2. Status Mutu Air Danau Rawapening (STORET) dibandingkan dengan BMA Kelas I, II, III dan IV (PP No. 82/2001)

\begin{tabular}{|c|c|c|c|c|c|c|c|c|}
\hline \multirow[b]{2}{*}{ Stasiun } & \multicolumn{2}{|c|}{ BMA Kelas 1} & \multicolumn{2}{|c|}{ BMA Kelas II } & \multicolumn{2}{|c|}{ BMA Kelas III } & \multicolumn{2}{|c|}{ BMA Kelas IV } \\
\hline & $\begin{array}{c}\text { Indeks } \\
\text { Storet }\end{array}$ & Status Mutu & $\begin{array}{l}\text { Indeks } \\
\text { Storet }\end{array}$ & Status Mutu & $\begin{array}{c}\text { Indeks } \\
\text { Storet }\end{array}$ & Status Mutu & $\begin{array}{c}\text { Indeks } \\
\text { Storet }\end{array}$ & Status Mutu \\
\hline $\mathrm{R} 1$ & -234 & $\begin{array}{l}\text { tercemar } \\
\text { berat }\end{array}$ & -49 & $\begin{array}{c}\text { tercemar } \\
\text { berat }\end{array}$ & -20 & $\begin{array}{l}\text { tercemar } \\
\text { sedang }\end{array}$ & 0 & memenuhi BMA \\
\hline $\mathrm{R} 2$ & -214 & $\begin{array}{c}\text { tercemar } \\
\text { berat }\end{array}$ & -64 & $\begin{array}{l}\text { tercemar } \\
\text { berat }\end{array}$ & -20 & $\begin{array}{l}\text { tercemar } \\
\text { sedang }\end{array}$ & 0 & memenuhi BMA \\
\hline R3 & -254 & $\begin{array}{l}\text { tercemar } \\
\text { berat }\end{array}$ & -81 & $\begin{array}{l}\text { tercemar } \\
\text { berat }\end{array}$ & -46 & $\begin{array}{l}\text { tercemar } \\
\text { berat }\end{array}$ & 0 & memenuhi BMA \\
\hline $\mathrm{R} 4$ & -248 & $\begin{array}{l}\text { tercemar } \\
\text { berat }\end{array}$ & -82 & $\begin{array}{l}\text { tercemar } \\
\text { berat }\end{array}$ & -42 & $\begin{array}{c}\text { tercemar } \\
\text { berat }\end{array}$ & 0 & memenuhi BMA \\
\hline $\mathrm{R} 5$ & -214 & $\begin{array}{l}\text { tercemar } \\
\text { berat }\end{array}$ & -70 & $\begin{array}{l}\text { tercemar } \\
\text { berat }\end{array}$ & -30 & $\begin{array}{l}\text { tercemar } \\
\text { sedang }\end{array}$ & 0 & memenuhi BMA \\
\hline R6 & -210 & $\begin{array}{l}\text { tercemar } \\
\text { berat }\end{array}$ & -70 & $\begin{array}{l}\text { tercemar } \\
\text { berat }\end{array}$ & -30 & $\begin{array}{l}\text { tercemar } \\
\text { sedang }\end{array}$ & 0 & memenuhi BMA \\
\hline $\mathrm{R} 7$ & -198 & $\begin{array}{l}\text { tercemar } \\
\text { berat }\end{array}$ & -61 & $\begin{array}{l}\text { tercemar } \\
\text { berat }\end{array}$ & -22 & $\begin{array}{l}\text { tercemar } \\
\text { sedang }\end{array}$ & 0 & memenuhi BMA \\
\hline
\end{tabular}

Tabel 3. Konsentrasi Parameter Kualitas Air yang Melebihi Baku Mutu Air Selama Observasi Di Masing-Masing Stasiun Pengamatan

\begin{tabular}{|c|c|c|c|c|c|c|c|c|c|c|}
\hline \multirow{2}{*}{ No } & \multirow{2}{*}{ Parameter } & \multirow{2}{*}{ Satuan } & \multicolumn{7}{|c|}{ Stasiun Pengamatan } & \multirow{2}{*}{ Rata-rata } \\
\hline & & & R1 & $\mathrm{R} 2$ & R3 & R4 & R5 & R6 & R7 & \\
\hline \multicolumn{11}{|c|}{ A.Fisika } \\
\hline 1 & TSS & mg..$^{-1}$ & 162.8 & 195.6 & 218.8 & 242.1 & 174.4 & 201.1 & 140.9 & 190.8 \\
\hline \multicolumn{11}{|c|}{ B. Kimia } \\
\hline 1 & Total P & $\operatorname{mg} .1^{-1}$ & 0.2 & 0.2 & 0.1 & 0.2 & 0.2 & 0.2 & 0.1 & 0.2 \\
\hline 2 & BOD & $\mathrm{mg} . \mathrm{l}^{-1}$ & 3.8 & 4.8 & 3.7 & 3.6 & 4.0 & 5.0 & 4.2 & 4.1 \\
\hline 3 & COD & mg. $1^{-1}$ & 22.1 & 24.5 & 26.6 & 25.4 & 25.9 & 29.2 & 26.2 & 25.7 \\
\hline 4 & $\mathrm{H}_{2} \mathrm{~S}$ & $\mathrm{mg} . \mathrm{l}^{-1}$ & 0.005 & 0.008 & 0.006 & 0.005 & 0.01 & 0.01 & 0.010 & 0.006 \\
\hline 5 & $\mathrm{Cd}$ & $\mathrm{mg} . \mathrm{l}^{-1}$ & 0.01 & 0.01 & 0.02 & 0.02 & 0.02 & 0.02 & 0.01 & 0.01 \\
\hline 6 & $\mathrm{~Pb}$ & $\mathrm{mg} . \mathrm{l}^{-1}$ & 0.03 & 0.03 & 0.03 & 0.04 & 0.02 & 0.03 & 0.02 & 0.03 \\
\hline \multicolumn{11}{|c|}{ B. Mikrobiologi } \\
\hline 1 & Total Coliform & ind $/ 100 \mathrm{ml}$ & 5,500 & 6,400 & 6,133 & 6,400 & 6,166 & 6,800 & 5,933 & 6.190 \\
\hline
\end{tabular}

TSS

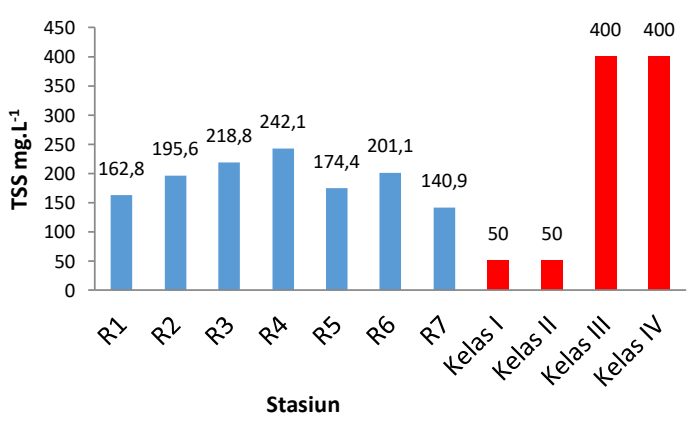

Gambar 1. Distribusi konsentrasi TSS dibandingkan dengan BMA kelas I, II, III, dan IV.

Menurut US-EPA pengaruh TSS sangat beragam, tergantung pada sifat kimia alamiah bahan tersuspensi tersebut. Secara fisika TSS sebagai penyebab kekeruhan pada air. Untuk zat padat tanpa bahan toksik yang nyata seperti tanah liat dapat mengganggu alat penglihatan dan permukaan tubuh lainnya, seperti insang khususnya pada ikan, Pengaruh keduanya terhadap perilaku ikan terjadi dalam bentuk penolakan ikan terhadap air keruh, hambatan makan dan peningkatan pencarian tempat berlindung. Selain itu kekeruhan juga mengurangi aktivitas dan mempengaruhi jalur migrasi ikan. Keberadaan TSS dengan konsentrasi tinggi juga dapat menyebabkan angka kematian yang tinggi terhadap Telur ikan yang disebabkan oleh penurunan aliran air dan oksigen terlarut ke dalam telur (Alabaster \& Lloyd, 1980). Keberadaan TSS di perairan yang melebihi batas ambang dapat menganggu kehidupan organisme perairan (Tarigan dan Edward, 2003).

Tingginya TSS di Danau Rawapening disebabkan tingginya tingkat erosi dari DTA. Hasil perhitungan laju erosi menunjukkan bahwa laju erosi pada Sub DAS Rawapening pada tahun 1991 sebesar 515,72 ton/ha meningkat menjadi 587,72 ton/ha pada tahun 2001 dan meningkat lagi menjadi 760,00 ton/ha pada tahun 2011 (Apriliyana, 2015). Tingginya tingkat erosi terlihat dari warna air sungai yang masuk ke Danau Rawapening berwarna kecoklatan yang membawa partikel-partikel tanah, namun dengan banyaknya eceng gondok dapat berfungsi sebagai filter yang mengikat partikel tanah tersebut sehingga dapat terendapkan. Disarankan oleh Soeprobowati dan Suedy (2010) bahwa ekoteknologi dengan menjadikan eceng gondok sebagai sabuk hijau, dan pembuatan pre-impoundment di hilir inlet sebelum 
masuk ke danau yang tujuannya adalah untuk menurunkan konsentrasi TSS.

Hal ini dimaksudkan agar tingkat Rawapening ini dapat menimbulkan fenomena eutrofikasi yang ditandai melimpahnya populasi tanaman Eceng Gondok (Eichhornia crassipes Solms) yang tidak terkendali. Gejala eutrofikasi di perairan Danau Rawapening dapat dikatakan telah mencapai tahapan akut sehingga mempengaruhi kondisi ekosistem Danau Rawapening (Purnomo et al., 2013).

Fosfor adalah salah satu elemen kunci yang diperlukan untuk pertumbuhan tanaman dan hewan dan di danau ekosistem cenderung menjadi nutrisi pembatas terjadinya kondisi eutrofikasi yang ditandai dengan pertumbuhan algae dan tanaman air di ekosistem perairan (Horne \& Goldmann, 1992). Forfor atau fosfat ada dalam tiga bentuk yaitu ortofosfat, metaphosphate (atau polifosfat) dan fosfat organik yang masing-masing terikat dalam senyawa fosfor dengan susunan kimia yang berbeda. Bentuk-bentuk fosfat (Total P) tersebut ada di dalam makhluk hidup dan tanaman/hewan yang membusuk akan melepaskan fosfat an organik atau ortofosfat $\left(\mathrm{PO}_{4}\right)$ dalam bentuk ion yang dapat langsung digunakan oleh algae dan tanaman air untuk pertumbuhannya. Fosfor (total P) juga diproduksi oleh proses alam yaitu hasil pelapukan batuan dan terbawa aliran runoff dari DTA masuk ke dalam sistem danau hanya sekitar $5-10 \%$ dalam bentuk terlarut dan sekitar 90 - $95 \%$ ditransport dalam bentuk terikat dengan partikel sedimen (Horne \& Goldmann, 1994).

Konsentrasi Total $\mathrm{P}$ di danau Rawapening di beberapa lokasi (R3 dan R7) masih berada di bawah BMA Kelas I dan II, sedangkan di stasiun lainnya telah berada di ambang batas BMA kelas I dan II yaitu sebesar 0.2 mg.L - $^{-1}$ (Gambar 2). Konsentrasi Total P di Danau Rawapening ini secara keseluruhan masih di bawah BMA air kelas III.

\section{Total P}

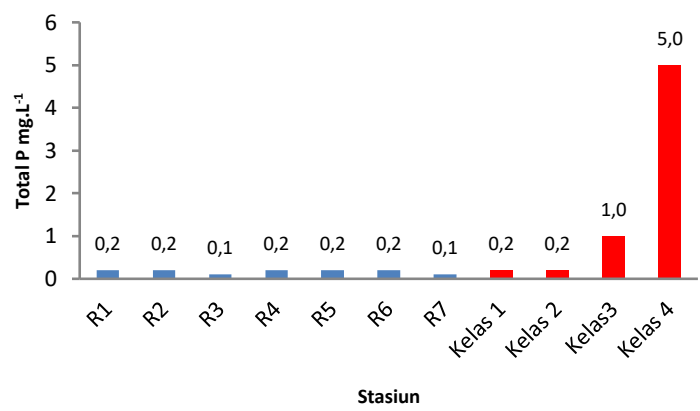

Gambar 2. Distribusi konsentrasi Total P dibandingkan dengan BMA kelas I, II, III, dan IV.

Hal ini berarti bahwa berdasarkan kandungan total $\mathrm{P}$, air Danau Rawapening masih sangat sesuai untuk peruntukan budidaya perikanan, sementara untuk memenuhi kebutuhan air baku air minum dan rekreasi air kandungan total $\mathrm{P}$ harus diturunkan. Penurunan konsentrasi Total $\mathrm{P}$ dapat dilakukan dengan membatasi kegiatan manusia di DTA dapat sebagai sumber P di perairan misalnya penggunaan pupuk yang berlebihan, aktifitas domestik dan limbah industri.

Berdasarkan penelitian Piranti et al, (2014) input Total fosfor dari daerah tangkapan air (DTA) ke danau Rawapening sebesar 10,32 mg/dt dan sebanyak 64,9\% tertinggal di sedimen danau sehingga danau Rawapening bertindak sebagai penyimpan TP dan apabila kondisi mendukung akan menyebabkan terjadinya kondisi eutrofikasi.

Eutrofikasi adalah pengkayaan perairan terutama oleh unsur nitrogen dan fosfor sehingga menyebabkan pertumbuhan tidak terkontrol dari algae maupun tumbuhan air (Klapper, 1991). Sumber nitrogen dan fosfor terutama berasal dari pupuk pertanian, perikanan, dan limbah rumah tangga. Dampak eutrofikasi yang sangat nyata adalah blooming eceng gondok, yang dari tahun ke tahun menunjukkan kecenderungan kenaikan persentasi penutupannya ke danau. Upaya pengelolaan melalui program pengangkatan biomassa eceng gondok telah dilakukan hampir setiap tahun, namun permasalahan tersebut belum teratasi secara maksimal. Dampak dari melimpahnya tanaman eceng gondok tersebut menimbulkan permasalahan kualitas air menjadi menurun.

Chemical Oxygen Demand (COD) dan Biochemical Oxygen Demand (BOD) adalah merupakan ukuran jumlah bahan organik di perairan. Perairan dengan nilai COD dan/atau BOD tinggi mengindikasikan bahwa air tersebut tercemar oleh bahan organik (Horne and Goldmann, 1992). Chemical Oxygen Demand (COD) adalah kebutuhan oksigen untuk proses dekomposisi bahan organik secara kimiawi. Deplesi oksigen yang terjadi di kolom air sangat dipengaruhi oleh konsentrasi BOD dan COD di dasar perairan (Cross and Summerfelt, 1987). Tingginya BOD/COD di kolom air disebabkan karena kondisi anoxic di dasar danau yang menggambarkan lambatnya proses decomposisi bahan organik di dasar perairan tersebut.

Konsentrasi COD di Danau Rawapening berkisar antara 22.1 - $29.2 \mathrm{mg} . \mathrm{L}^{-1}$ (Gambar 3). Hal ini sudah jauh melampaui BMA kelas I sebesar $10 \mathrm{mg} . \mathrm{L}^{-1}$. Baku mutu air (BMA) kelas II mensyaratkan konsentrasi COD tidak melebihi 25 mg.L. ${ }^{-1}$. Berdasarkan ketentuan tersebut maka air Danau Rawapening sudah tidak layak bila dimanfaatkan sebagai air baku air minum dan sarana rekreasi.

Konsentrasi BOD Danau Rawapening di semua stasiun pengamatan menunjukkan telah melebihi BMA Kelas I dan II yaitu berkisar 3.7 - 4.9 mg. $\mathrm{L}^{-1}$, namun belum melampaui BMA Kelas III dan IV (Gambar 4).

Konsentrasi $\mathrm{BOD}_{5}$ yang dipersyaratkan untuk BMA Kelas I adalah sebesar $2 \mathrm{mg} . \mathrm{L}^{-1}$ dan Kelas II adalah sebesar $3 \mathrm{mg} . \mathrm{L}^{-1}$, dan Kelas III sebesar $6 \mathrm{mg} . \mathrm{L}^{-1}$ serta Kelas IV sebesar 12 mg.L ${ }^{-1}$. Oleh karena itu, berdasarkan konsentrasi BOD nya maka air Danau Rawapening sudah tidak sesuai bila digunakan untuk keperluan air baku minum dan sarana rekreasi, namun untuk kegiatan budidaya perikanan menunjukkan tidak ada permasalahan.

Kekeruhan yang disebabkan oleh konsentrasi TSS di Danau Rawapening tidak sampai taraf mengganggu 
kehidupan ikan dan organisme perairan lainnya yang hidup di perairan danau tersebut.

Tingginya TSS di Danau Rawapening juga mengindikasikan bahwa bahan organik dan an organik (nutrient) di danau cukup tinggi (Tarigan dan Edward, 2003). Tingginya nutrient dan bahan organik di Danau

\section{COD}

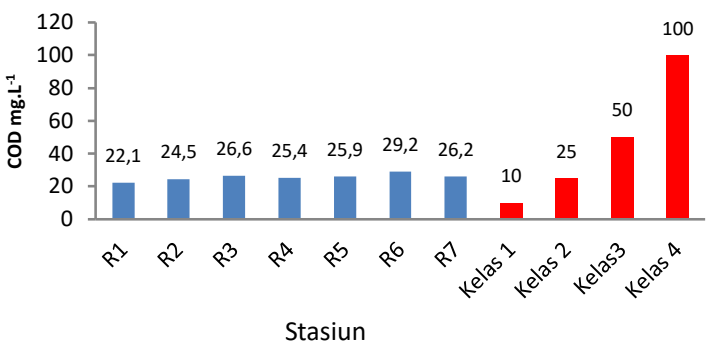

Gambar 3. Distribusi konsentrasi COD dibandingkan dengan BMA Kelas I, II, III, dan IV

BOD

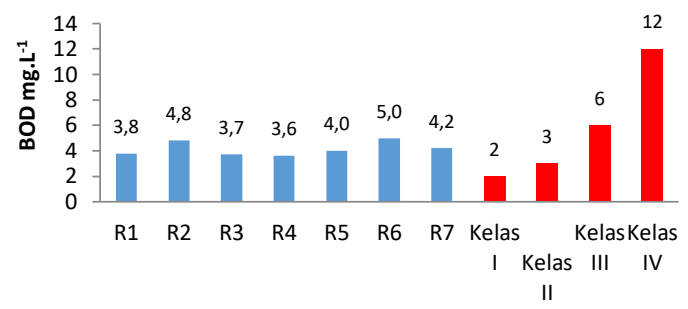

Stasiun

\section{Gambar 4. Distribusi konsentrasi BOD dibandingkan} dengan BMA Kelas I, II, III, dan IV

Perairan dengan nilai BOD tinggi mengindikasikan bahwa air tersebut tercemar oleh bahan organik. Tingginya BOD di Danau Rawapening salah satu penyebabnya adalah adanya kegiatan budidaya menggunakan karamba jaring apung (KJA). Berdasarkan data Dinas Peternakan dan Perikanan Kabupaten Semarang tahun 2012, sampai dengan tahun 2011 jumlah karamba yang berada di Danau Rawapening berjumlah 452 unit. Total pakan yang diberikan sebanyak $1.979,76$ ton pakan/tahun (Samudra, Soeprobowati, dan Izzati, 2012) dengan Nilai Feed Convertion Ratio (FCR) sebesar 1,83 yang umumnya sebesar 1,50. Hal tersebut menunjukkan bahwa jumlah pakan yang diberikan oleh petani ikan karamba di Danau Rawapening masih kurang efisien (Erlania et al, 2010). Pemberian pakan yang tidak efisien dapat menyebabkan masuknya bahan organik yang berlebihan ke perairan dan mengakibatkan terjadinya pencemaran bahan organik.

Bahan organik akan didekomposisi secara biologik dengan melibatkan bakteri pengurai melalui sistem oksidasi aerobik dan anaerobik. Konsentrasi oksigen terlarut rata-rata di permukaan Danau Rawapening adalah $3.25 \mathrm{mg} . \mathrm{L}^{-1}$. Nilai tersebut masih memenuhi batas minimum konsentrasi oksigen terlarut sesuai BMA Kelas III untuk perikanan. Semakin tinggi konsentrasi oksigen terlarut semakin bagus untuk kehidupan biota akuatik di perairan. Konsentrasi oksigen terlarut di dasar perairan adalah $1,02 \mathrm{mg} . \mathrm{L}^{-1}$. Hal ini menunjukkan bahwa telah terjadi penurunan konsentrasi oksigen terlarut yang digunakan untuk proses dekomposisi bahan organik secara aerob di dasar perairan. Nitrifikasi merupakan oksidasi ammonia menjadi nitrit dan nitrat. Proses oksidasi ini dilakukan oleh bakteri aerob yang berperan menguraikan bahan organic dengan adanya oksigen. Oksidasi aerobik dapat menyebabkan penurunan kandungan oksigen terlarut di perairan sampai pada tingkat terendah, sehingga kondisi perairan menjadi anaerobik yang dapat mengakibatkan kematian organisme akuatik dan terganggunya proses nitrifikasi (Effendi, 2003). Pengukuran oksigen terlarut pada saat observasi ini dilakukan pada siang hari sehingga pada saat tersebut masih dimungkinkan adanya suplai oksigen dari hasil fotosintesis oleh algae dan tanaman air ke dasar perairan. Kondisi anaerob dimungkinkan terjadi pada malam hari ketika tidak ada suplai oksigen dari aktifitas fotosintesis oleh algae dan tanaman air, sehingga terjadi deplesi oksigen akibat banyaknya oksigen yang digunakan untuk proses aerob dan respirasi organisme, sehingga kondisinya menjadi anaerobik. Dalam kondisi anaerob yang terjadi pada malam hari tersebut akan dihasilkan senyawa-senyawa $\mathrm{NH}_{3}, \mathrm{H}_{2} \mathrm{~S}, \mathrm{CH}_{4}$ yang berbau tidak sedap.

Hidrogen Sulfida $\left(\mathrm{H}_{2} \mathrm{~S}\right)$ merupakan gas berbau busuk yang dihasilkan dari proses penguraian senyawa belerang dari bahan organik oleh bakteri anaerob yang terjadi pada air tercemar yang tidak mengandung oksigen terlarut. Proses anaerob ini biasanya terjadi di perairan yang airnya tidak bersirkulasi dan tidak mempunyai kontak langsung dengan udara sehingga mengurangi kemampuan air untuk melarutkan oksigen. Semakin berat tingkat pencemaran air maka oksigen terlarut semakin sedikit begitu juga dengan jenis organisme aerobnya. Ketika oksigen terlarut tidak tersedia lagi maka penguraian bahan organik akan dilakukan oleh mikroorganisme anaerob yang mengeluarkan gas asam sulfida $\left(\mathrm{H}_{2} \mathrm{~S}\right)$ dan gas metana $\left(\mathrm{CH}_{4}\right)$ (Purnomo et al., 2013). Tingginya konsentrasi sulfida $\left(\mathrm{H}_{2} \mathrm{~S}\right)$ pada air Danau Rawapening tersebut menunjukkan bahwa adanya proses degradasi bahan organik secara anaerob. Menurut baku mutu air kelas III, konsentrasi $\mathrm{H}_{2} \mathrm{~S}$ dalam suatu perairan harus tidak melebihi 0.002 mg. $\mathrm{l}^{-1}$. Konsentrasi $\mathrm{H}_{2} \mathrm{~S}$ di Danau Rawapening sudah sangat tinggi di setiap lokasi pengukuran yaitu berkisar $0.005-0.01 \mathrm{mg} / \mathrm{l}$ dan telah jauh melebihi baku mutu kelas III dan bahkan kelas IV (Gambar 5). Namun demikian kondisi tersebut belum menimbulkan permasalahan bau yang mengganggu bagi pengunjung.

Konsentrasi tertinggi berada di daerah Muara Sungai Legi dan Muncul (R5), Muara Sungai Kedungringin (R6), dan daerah outlet danau (Sungai Tuntang) (R7). Di lokasi R5 merupakan daerah inlet utama danau yang 
berasal dari masukan Sungai Muncul. Di area ini terdapat lokasi yang dipergunakan untuk kegiatan pariwisata seperti kolam renang dan restauran sehingga sampah dan limbah yang masuk ke danau mengalami pembusukan yang melepaskan gas $\mathrm{H}_{2} \mathrm{~S}$.

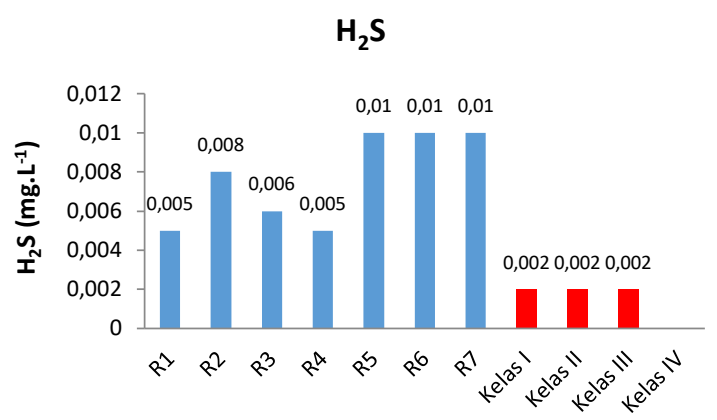

Stasiun

Gambar 5. Distribusi konsentrasi $\mathrm{H}_{2} \mathrm{~S}$ dibandingkan dengan BMA Kelas I, II, III, dan IV

Gas $\mathrm{H}_{2} \mathrm{~S}$ bersifat racun tergantung pada keadaan ionisasinya. Hidrogen sulfida yang tidak terionisasi sangat beracun bagi ikan, tetapi dalam bentuk lain tidak beracun. Daya racun paling berbahaya adalah pada keadaan $\mathrm{pH}$ rendah dan kondisi anaerob. Jika kandungan oksigen meningkat maka sulfur akan teroksidasi dalam bentuk ion seperti sulfat sehingga menurunkan pembentukan hidrogen sulfida. Nilai $\mathrm{pH}$ menentukan perubahan sulfur antara jenis sulfur $\left(\mathrm{H}^{2} \mathrm{~S}\right.$, $\mathrm{HS}^{-}$dan $\mathrm{S}^{2-}$ ). Naiknya $\mathrm{pH}$ air mengakibatkan persentase hidrogen sulfida berkurang (Henny dan Nomosatryo, 2012).

Indikator kualitas air juga didasarkan pada parameter biologi yaitu total bakteri coliform yang jumlahnya tidak melebihi 1.000/100 ml untuk BMA air kelas 1, 5.000/100 ml untuk BMA Kelas II, dan 10.000/100 ml untuk BMA Kelas III dan IV. Bakteri coliform tidak menyebabkan penyakit. Namun, kehadiran mereka di air menunjukkan bahwa organisme penyebab penyakit (patogen) bisa hadir dalam sistem air tersebut. Selama observasi jumlah bakteri coliform air Danau Rawapening mengandung sekitar 5.500/100 ml 6.800/100 ml (Gambar 6). Apabila dibandingkan dengan BMA sesuai peruntukannya maka di semua stasiun pengamatan sudah tidak sesuai untuk dimanfaatkan sebagai sumber air baku air minum dan tempat rekreasi air, namun masih sesuai untuk budidaya perikanan dan air untuk peruntukan lain yang mempersyaratkan mutu air yang sama dengan kegunaan tersebut.

Keberadaan logam berat di perairan dapat memberikan dampak negatif bagi kehidupan organisme air dari tingkatan individu sampai dengan tingkatan komunitas. Tingginya konsentrasi logam $\mathrm{Cd}$ dan $\mathrm{Pb}$ akibat dari kegiatan manusia seperti pertambangan, pembuangan limbah rumah tangga, limbah buangan industri serta aliran dari pertanian merupakan sumber utama pemasukan logam ke dalam lingkungan perairan.
Berdasarkan observasi yang dilakukan pada musim kemarau (Juli - September 2016), Danau Rawapening telah tercemar logam berat $\mathrm{Cd}$ dan $\mathrm{Pb}$ (Tabel 1). Konsentrasi logam $\mathrm{Pb}$ di Danau Rawapening berkisar antara $0.2-0.3 \mathrm{mg} . \mathrm{L}^{-1}$ dan telah melebihi BMA yang dipersyaratkan apabila peruntukannya digunakan sebagai sumber baku air minum, sarana rekreasi air dan kegiatan perikanan. Logam berat $\mathrm{Pb}$ ini sudah mencemari Danau Rawapening tidak hanya di air namun juga telah ada di sedimen dan bahkan di ikan meskipun di ikan konsentrasinya masih di bawah baku mutu batas cemaran logam dalam pangan sesuai SNI 7387 : 2009 (Hidayah et al, 2012).

Ikan Nila di Danau Rawapening telah mengandung $\mathrm{Pb}$ sebesar 0,18 mg/kg (Hidayah et al, 2012). Adanya kandungan logam berat $\mathrm{Pb}$ pada ikan dikarenakan logam berat dapat diabsorpsi oleh ikan melalui rantai makanan. Hal ini didukung oleh Paundanan et al (2015) bahwa konsentrasi logam $\mathrm{Pb}$ akan diabsorbsi oleh ikan dan konsentrasi tertinggi ke terendah berturut-turut terdeteksi di dalam organ limpa > hati > insang $>$ daging. Oleh karena itu, untuk mengkonsumsi ikan yang berasal dari Danau Rawapening harus diperhitungkan agar tidak membahayakan kesehatan. Menurut WHO batas asupan makanan yang mengandung logam berat $\mathrm{Pb}$ adalah $0.2-0.3 \mathrm{mg} / \mathrm{hari}$ tiap orang.

Stasiun pengamatan $\mathrm{R} 4$ konsentrasi logam berat $\mathrm{Pb}$ nya paling tinggi di antara stasiun lainnya dan telah melampaui baku mutu kelas I, II dan III sebesar 0.4 $\mathrm{mg} \cdot \mathrm{L}^{-1} .\left(\mathrm{BMA}<0.3 \mathrm{mg} \cdot \mathrm{L}^{-1}\right)($ Gambar 7$)$.

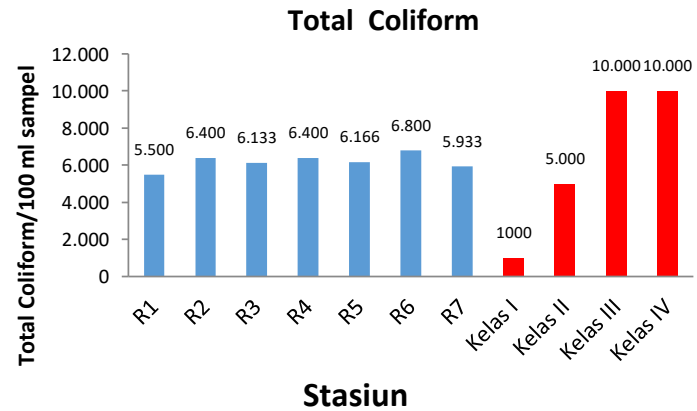

Gambar 6. Distribusi konsentrasi Total Coliform dibandingkan dengan BMA Kelas I, II, III, dan IV

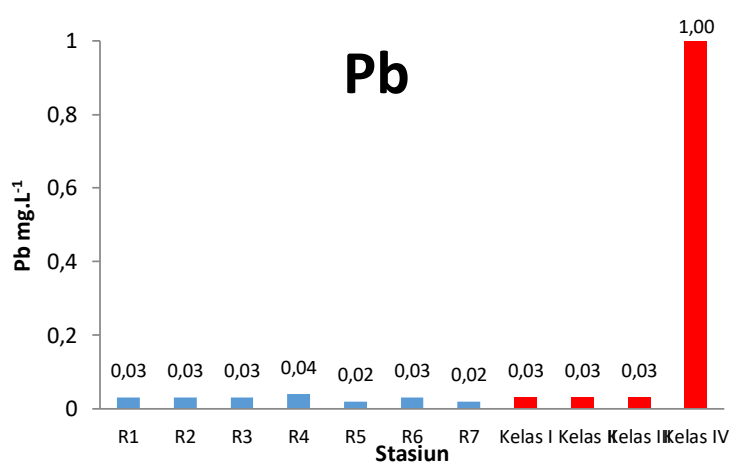

Gambar 7. Distribusi konsentrasi Logam Pb dibandingkan dengan BMA Kelas I, II, III, dan IV 
Tingginya konsentrasi logam $\mathrm{Pb}$ di stasiun $\mathrm{R} 4$ karena lokasi tersebut merupakan daerah yang digunakan untuk budidaya ikan menggunakan KJA. Selain akibat adanya aktifitas $\mathrm{KJA}$, kandungan logam $\mathrm{Pb}$ yang tinggi yang ada di Rawapening juga berasal dari proses alami. Logam $\mathrm{Pb}$ yang berasal dari proses alami yaitu pada saat pembentukan Danau Rawapening yang diakibatkan dari letusan vulkanik (Soeprobowati, 2011). Aktivitas manusia yang dapat meningkatkan kandungan $\mathrm{Pb}$ di perairan Danau Rawapening pariwisata adalah karena aktivitas pariwisata yang memanfaatkan jasa kapal motor yang berbahan bakar solar dan bensin. Hasil pembakaran (asap) dari kapal motor tersebut dapat menghasilkan $\mathrm{Pb}$ yang terakumulasi ke badan perairan (Hidayah et al, 2012; Sundra dan Joni, 2015). Sundra dan Joni (2015) mengkaji distribusi $\mathrm{Pb}$ di Danau Batur yang menunjukkan bahwa terjadi peningkatan konsentrasi $\mathrm{Pb}$ pada lokasi-lokasi yang merupakan area pariwisata yang sarat aktivitas kapal motor yang digunakan untuk menunjang pariwisata air. Sedangkan cemaran pestisida kemungkinan dihasilkan dari kegiatan pertanian di daerah hulu sungai-sungai yang masuk ke danau.

Tingginya logam $\mathrm{Pb}$ di perairan akan berakibat terabsorbsi oleh ikan yang dibudidayakan pada perairan tersebut sehingga ikan tersebut menjadi potensial terkontaminasi oleh logam berat. Apabila ikan yang sudah tercemar oleh logam berat dikonsumsi, akan berpotensi menimbulkan berbagai penyakit baik jangka pendek maupun jangka panjang, tergantung konsentrasi maupun kondisi penderita.

Kadmium merupakan bahan beracun yang menyebabkan keracunan kronik pada manusia, maka tingkat maksimun yang diperbolehkan di perairan adalah 0,01 mg/L (PP No 82 Th 2001). Kadmiun (Cd) adalah logam berat yang secara normal terdapat pada tanah dan air dalam kadar rendah. Kadmium berasal dari beberapa sumber yaitu sumber alami, pertambangan dan industri. Gunung berapi merupakan sumber kadmium terbesar secara alami. Kandungan logam Cd di perairan Danau Rawapening berkisar antara $0.01-0.02 \mathrm{mg} . \mathrm{L}^{-1}$. Konsentrasi logam Cd di R1, R2, dan R7 konsentrasinya sama dengan BMA yang ditetapkan, namun di stasiun R3, R4, R5, dan R6 telah jauh melebihi BMA untuk semua kelas (Gambar 8). Berdasarkan kandungan logam $\mathrm{Cd}$ maka danau air Danau Rawapening tidak layak digunakan untuk berbagai akitivitas yang mensyaraktakan kualitas air tertentu. Tingginya konsentrasi logam Cd di Danau Rawapening akan berdampak pada manusia yang memanfaatkan air untuk kebutuhan domestiknya. Tingginya kandungan kadmium di perairan danau akhirnya akan sampai pada manusia apabila manusia mengkonsumsi ikan hasil tangkapan di perairan yang tercemar logam tersebut.

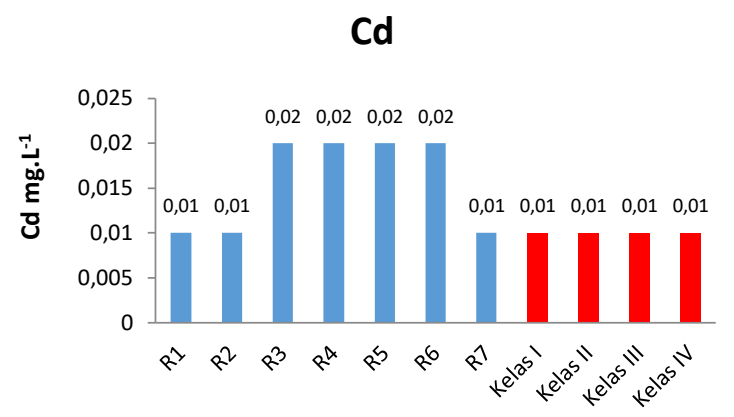

Stasiun

Gambar 8. Distribusi konsentrasi Logam Cd dibandingkan dengan BMA Kelas I, II, III, dan IV

Stasiun R3 adalah mata air artesis yang merupakan mata air utama yang menjadi sumber air bagi danau Rawapening. Seperti juga logam $\mathrm{Pb}$, sumber logam $\mathrm{Cd}$ juga berasal dari proses alami yaitu berasal dari aktivitas vulkanik terbentuknya danau (Soeprobowati, 2011). Stasiun R4, R5, R6 adalah daerah outlet dari sungai-sungai yang masuk ke Danau Rawapening yang melewati daerah pertambangan. Adanya penambangan galian golongan $\mathrm{C}$ yang tidak terkendali untuk mengambil galian andesit, dan bahan galian sirtu di Kecamatan Bawen, Kecamatan Tuntang, Kecamatan Bringin menjadi penyebab munculnya permasalahan tanah longsor yang membawa logam-logam berat dan melalui aliran run off menuju sungai dan akhirnya ke Danau Rawapening.

Pupuk pertanian di DTA khususnya pupuk fosfat juga mengandung logam berat $\mathrm{Pb}$ antara $5-156 \mathrm{ppm}$ (Hidayat. 2015) dan 7 ppm Cd untuk tanah netral. Perilaku penggunaan lahan mengindikasikan bahwa ada hubungan antara dampak penggunaan pupuk pada lahan pertanian dan sawah terhadap kualitas air (Rahman, Purwanto, \& Suprihatin, 2014). Apabila pupuk tersebut digunakan secara terus menerus dengan dosis dan intensitas yang tinggi dapat meningkatkan $\mathrm{Pb}$ dan Cd yang tersedia dalam tanah sehingga ketika air limpasan melewati areal pertanian tersebut dapat meningkatkan konsentrasi $\mathrm{Pb}$ dan $\mathrm{Cd}$ di perairan. Stasiun R1 adalah muara sungai Torong dan Galeh yang berada di antara areal persawahan dimana hulunya di pegunungan Telomoyo. Kedua sungai tersebut tidak melewati areal pertambangan namun melewati areal persawahan jadi konsentrasi logam yang terkandung relatif lebih rendah. Stasiun R2 merupakan Lokawisata "Bukit Cinta", sehingga beban pencemar logam Cd yang masuk berasal dari aktivitas wisata dan dari limbah bahan bakar oli untuk penggunaan perahu wisata. Stasiun R7 konsentrasi logam Cd relatif rendah. Hal ini ada kaitannya dengan fungsi danau sebagai PLTA. Pada saat dilakukan observasi pintu PLTA Jelok dalam kondisi ditutup (hanya dioperasikan pada malam hari). Dengan kondisi tersebut maka aliran air keluar danau menjadi lambat dan memungkinkan logamlogam akan mengendap, sehingga konsentrasi logam di outlet relatif lebih kecil. 
Berdasarkan peruntukaanya, air danau rawapening saat ini dimanfaatkan untuk sumber baku air minum, sarana rekreasi, kegiatan perikanan tangkap dan budidaya dan penyedia air irigasi. Oleh karena itu, seharusnya status mutu airnya harus memenuhi BMA kelas I. Namun demikian berdasarkan parameter kualitas air yang dipersyaratkan sesuai PP nomor 82 tahun 2001 tidak ada satupun parameter yang dapat memenuhi BMA Kelas 1. Ke 8 (delapan) parameter tersebut telah melebihi BMA Kelas I bahkan telah melebihi BMA kelas II dan III. Rangkuman status mutu air berdasarkan parameter yang melebihi BMA sesuai peruntukannya seperti terlihat pada Tabel 3.

Tabel 3. Status Mutu Air Danau Rawapening Dibandingkan Dengan Baku Mutu Air Sesuai Peruntukannya

\begin{tabular}{|c|c|c|c|c|c|c|}
\hline \multirow{2}{*}{ Parameter } & \multirow{2}{*}{ Satuan } & \multirow{2}{*}{$\begin{array}{c}\text { Kisaran } \\
\text { konsentrasi }\end{array}$} & \multicolumn{4}{|c|}{ Status Mutu Air Dibandingkan BMA Sesuai Kelas Air } \\
\hline & & & $\mathrm{I}$ & II & III & IV \\
\hline TSS & $\mathrm{mg} \cdot \mathrm{L}^{-1}$ & $140,9-242,1$ & $\begin{array}{c}\text { Tidak } \\
\text { memenuhi }\end{array}$ & $\begin{array}{c}\text { Tidak } \\
\text { memenuhi }\end{array}$ & Memenuhi & Memenuhi \\
\hline Total P & $\mathrm{mg} \cdot \mathrm{L}^{-1}$ & $0,1-0,2$ & $\begin{array}{c}\text { Tidak } \\
\text { memenuhi }\end{array}$ & $\begin{array}{c}\text { Tidak } \\
\text { memenuhi }\end{array}$ & Memenuhi & Memenuhi \\
\hline COD & $\mathrm{mg} \cdot \mathrm{L}^{-1}$ & $22,1-29,2$ & $\begin{array}{c}\text { Tidak } \\
\text { memenuhi }\end{array}$ & $\begin{array}{c}\text { Tidak } \\
\text { memenuhi }\end{array}$ & Memenuhi & Memenuhi \\
\hline BOD & $\mathrm{mg} \cdot \mathrm{L}^{-1}$ & $3,6-5,0$ & $\begin{array}{c}\text { Tidak } \\
\text { memenuhi }\end{array}$ & $\begin{array}{c}\text { Tidak } \\
\text { memenuhi }\end{array}$ & Memenuhi & Memenuhi \\
\hline $\mathrm{H}_{2} \mathrm{~S}$ & $\mathrm{mg} \cdot \mathrm{L}^{-1}$ & $0,005-0,01$ & $\begin{array}{c}\text { Tidak } \\
\text { memenuhi }\end{array}$ & $\begin{array}{c}\text { Tidak } \\
\text { memenuhi }\end{array}$ & $\begin{array}{c}\text { Tidak } \\
\text { memenuhi }\end{array}$ & $\begin{array}{c}\text { Tidak } \\
\text { memenuhi }\end{array}$ \\
\hline $\begin{array}{c}\text { Total } \\
\text { Coliform }\end{array}$ & Ind $/ 100 \mathrm{ml}$ & $5.500-6.800$ & $\begin{array}{c}\text { Tidak } \\
\text { memenuhi }\end{array}$ & $\begin{array}{c}\text { Tidak } \\
\text { memenuhi }\end{array}$ & Memenuhi & Memenuhi \\
\hline Logam $\mathrm{Pb}$ & $\mathrm{mg} \cdot \mathrm{L}^{-1}$ & $0,02-0,03$ & $\begin{array}{c}\text { Tidak } \\
\text { memenuhi }\end{array}$ & $\begin{array}{c}\text { Tidak } \\
\text { memenuhi }\end{array}$ & $\begin{array}{c}\text { Tidak } \\
\text { memenuhi }\end{array}$ & Memenuhi \\
\hline Logam Cd & $\mathrm{mg} \cdot \mathrm{L}^{-1}$ & $0,01-0,02$ & $\begin{array}{c}\text { Tidak } \\
\text { memenuhi }\end{array}$ & $\begin{array}{c}\text { Tidak } \\
\text { memenuhi }\end{array}$ & $\begin{array}{c}\text { Tidak } \\
\text { memenuhi }\end{array}$ & $\begin{array}{c}\text { Tidak } \\
\text { memenuhi }\end{array}$ \\
\hline
\end{tabular}

Tabel 3 memperlihatkan bahwa Danau Rawapening tidak dapat memenuhi BMA kelas I dan II, namun hanya memenuhi BMA Kelas III dan IV. Hal ini berarti bahwa air Danau Rawapening tidak layak apabila dimanfaatkan sebagai air baku air minum dan sarana rekreasi air, namun hanya dapat dimanfaatkan untuk perikanan dan air pertamanan. Ada 5 parameter yang dapat menunjukkan bahwa air Danau Rawapening dapat dimanfaatkan untuk kegiatan perikanan (Kelas III) dan pertamanan (Kelas IV) atau peruntukan lain yang mempersyaratkan mutu air yang sama dengan kegunaan tersebut. Parameter tersebut adalah TSS, Total P, Total Coliform, COD, BOD. Berdasarkan kandungan logam $\mathrm{Pb}$ air Danau Rawapening dapat digunakan sebagai air pertamanan (Kelas IV) tapi sudah membahayakan apabila untuk kegiatan perikanan karena sifatnya yang akumulatif dan akan meracuni organisme perairan, demikian juga dengan logam Cd. Berdasarkan konsentrasi $\mathrm{H}_{2} \mathrm{~S}$, air Danau Rawapening sudah membahayakan untuk semua peruntukan. Terbentuknya $\mathrm{H}_{2} \mathrm{~S}$ tidak dapat dihindari di Danau Rawapening karena sedimen danau terdiri atas tanah gambut. Ketika oksigen terlarut tidak tersedia lagi maka penguraian tanah gambut akan dilakukan oleh secara anaerob yang mengeluarkan gas asam sulfida $\left(\mathrm{H}_{2} \mathrm{~S}\right)$ dan gas metana $\left(\mathrm{CH}_{4}\right)$. Oleh karena itu, upaya yang bisa dilakukan untuk menurunkan $\mathrm{H}_{2} \mathrm{~S}$ ini di antaranya adalah dengan melakukan aerasi agar kondisi danau menjadi aerob atau dengan mengangkat tanah gambut tersebut seperti yang selama ini telah dilakukan dan dapat dimanfaatkan sebagai pupuk organik.

\section{Kesimpulan}

Status mutu air Danau Rawapening termasuk kategori tercemar berat. Delapan parameter yang melebihi baku mutu air Kelas II adalah BOD,COD, TSS, $\mathrm{PO}_{4}$, Total Coliform; sedangkan parameter logam $\mathrm{Cd}, \mathrm{Pb}$, dan gas $\mathrm{H}_{2} \mathrm{~S}$ telah melebihi baku mutu air Kelas III. Berdasarkan status mutunya maka peruntukan air Danau Rawapening hanya layak digunakan sesuai dengan kriteria Kelas III (untuk kegiatan perikanan) dan Kelas IV (mengairi pertamanan).

\section{Ucapan Terimakasih}

Penulis menyampaikan ucapan terimakasih kepada Direktorat Jenderal Pendidikan Tinggi (DIKTI) yang telah memberikan dana penelitian melalui Skim Hibah Fundamental Tahun Anggaran 2016.

\section{Daftar Pustaka}

[1] Alabaster, J.S. Lloyd R. (Eds.), 1980.Water Quality Criteria for Freshwater Fish, 2nd Ed. Butterworths, London,

[2] APHA, 1992. Standard Methods for the Examination of Water and Wastewater. American Public Health Association (APHA), American Water Works Association (AWWA), Water Pollution Control Federation (WPCF). Washington DC.

[3] Apriliyana, D., 2015. Pengaruh Perubahan Penggunaan Lahan Sub DAS Rawapening terhadap Erosi dan Sedimentasi Danau Rawapening, 11(1), pp. 103-116.

[4] Badan Perencanaan Pembangunan Daerah (BPPD), Propinsi Jawa Tengah. 2000. Penyusunan Rencana Pengelolaan Kawasan Rawapening Propinsi Jawa Tengah.

[5] Badan Pusat Statistik, 2016. Kabupaten Semarang Dalam Angka. Semarang. Jawa Tengah

[6] Cross, T.K., Summerfelt, RC., 1987. Oxygen Demand of Lakes: Sediment and Water Column BOD. Lake and Reservoir Management. 3(1), pp. 109-116. 
[7] Erlania, Rusmaedi, A.B. Prasetio, J. Haryadi, 2010. Dampak Manajemen Pakan Dari Kegiatan Budidaya Ikan Nila (Oreochromis niloticus) Di Keramba Jaring Apung Terhadap Kualitas air. Prosiding Forum Inovasi Teknologi Akuakultur, 2002, pp.621-631.

[8] Esta, K.A., P. Suarya, D.A. Suastuti, 2016. Penentuan Status Mutu Air Tukad Yeh Poh Dengan Metode Storet. Jurnal Kimia, $10(1)$, pp. 65-67.

[9] Henny, C., S. Nomosatryo, 2012. Dinamika Sulfida Di Danau Maninjau : Implikasi Terhadap Pelepasan Fosfat Di Lapisan Hipolimnion. Prosiding Seminar Nasional Limnologi VI Tahun 2012. Bogor, Indonesia

[10] Hidayah, A.M.1., Purwanto, R. Soeprobowati, 2012. Kandungan Logam Berat pada Air, Sedimen dan Ikan Nila (Oreochromis niloticus Linn.). Prosiding Seminar Nasional Pengelolaan Sumberdaya Alam dan Lingkungan, (September), pp 95-101.

[11] Hidayat, B., 2015. Remediasi Tanah Tercemar Logam Berat Dengan Menggunakan Biochar. Jurnal Pertanian Tropik. 2(1), pp 31- 41 .

[12] Horne, A.J. and C.R. Goldman, 1994. Lymnology. Second edition. McGraw Hill, Inc. New York.

[13] Klapper, H., 1991. Control of Eutrophication In Inland Waters. Ellis Horwood. New York, London.

[14] Kementrian KLH, 1988. Keputusan Menteri Negara KLH Tentang Pedoman Penetapan Baku Mutu Lingkungan, Kementrian KLH, Jakarta.

[15] Kementrian Lingkungan Hidup, 2011. Profil 15 Danau Prioritas Nasional. Jakarta, Indonesia

[16] Nurmalita, Maulidia, dan M. Syukri, 2013. Analisa Kekeruhan Dan Kandungan Sedimen Dan Kaitannya Dengan Kondisi Das Sungai Krung Aceh. Seminar Nasional Pengelolaan Daerah Aliran Sungai Berbasis Masyarakat Menuju Hutan Aceh Berkelanjutan, Banda Aceh, 1.

[17] Paundanan, M., E. Riani, dan S. Anwar, 2015. Heavy Metals Contamination Mercury $(\mathrm{Hg})$ and Lead $(\mathrm{Pb})$ in Water, Sediment and Torpedo Scad Fish (Megalaspis cordyla L) in Palu Bay, Sentral Sulawesi). Journal of Natural Resources and Environmental Management, 5(2), pp.161-168.

[18] Paimin, A. Wuryanta, U. Murtiono, 2012. Identifikasi Kerentanan Lahan Di Daerah Tangkapan Air Sebagai Dasar Pelestarian Danau Rawa Pening. Prosiding Seminar Nasional Limnologi VI Tahun 2012, pp. 125-135.

[19] Peraturan Pemerintah Nomor 82 Tahun 2001 tentang pengelolaan kualitas air dan pengendalian pencemaran.
[20] Peraturan Gubernur Jawa Tengah Nomor 5 Tahun 2014 Tentang Peruntukan Air Dan Pengelolaan Kualitas Air Sungai Tuntang Di Provinsi Jawa Tengah.

[21] Piranti, A.S., 2014. Input of Nutrient (Nitrogen And Phosphorus) From The Catchment Area Into Rawapening Lake Of Central Java. Prosiding Seminar International Basic Science (IBSC). Jember, Indonesia.

[22] Purnomo, P.W., M. Nitisupardjo, Y. Purwandari, 2013. Hubungan Antara Total Bakteri Dengan Bahan Organik, $\mathrm{NO}_{3}$ dan $\mathrm{H}_{2} \mathrm{~S}$ Pada Lokasi Sekitar Eceng Gondok dan Perairan Terbuka Di Rawa Pening. Journal of Management of Aquatic Resources. 2(3), pp. 74-84.

[23] Rahman, M.W., M.Y.J. Purwanto, dan Suprihatin, 2014 Status Kualitas Air dan Upaya Konservasi Sumberdaya Lahan di DAS Citarum Hulu, Kabupaten Bandung. Jurnal Pengelolaan Sumberdaya Alam Dan Lingkungan. 4(1), pp. 24-34.

[24] Samudra, S.R., T.R. Soeprobowati, dan M. Izzati, 2012. Daya tampung beban pencemaran fosfor untuk budidaya perikanan danau rawapening, (Laporan Penelitian), pp. 134-142.

[25] Soeprobowati, T.R., S.W.A. Suedy, 2010. Status trofik danau rawapening dan solusi pengelolaannya. Jurnal Sains Dan Matematika. 18(2005), pp. 158-169.

[26] Soeprobowati, T.R., 2011. Kajian Perubahan Ekosistem Danau Rawapening Menggunakan Diatom sebagai Bioindikator. Prosiding. Semarang: Simposium Nasional Penelitian Perubahan Iklim. Kementerian Lingkungan Hidup bekerjasama dengan UNDIP.

[27] Sundra, I.K., M. Joni, 2015. Inovasi humaniora, sains dan teknologi untuk pembangunan berkelanjutan. Prosiding Seminar Nasional Sains Dan Teknologi, Kuta 29-30 Oktober 2015. pp. 2166-2172.

[28] Suwanto, A., T.N. Harahap, H. Manurung, W.C. Rustadi, S.R. Nasution, I.N.N. Suryadiputra, I. Sualia, 2011. Profil 15 Danau Prioritas Nasional. Kementerian Lingkungan Hidup. Indonesia.

[29] Tarigan, M.S., dan E. Edward, 2003. Kandungan Total Zat Padat Tersuspensi (Total Suspended Solid) di Perairan Raha, Sulawesi Tenggara. Makara Sains. 7 (3), pp. 109-119.

[30] US Environmental Protection Agency (U.S. EPA), 1972. Water Quality Criteria, EPA-R3-73-033-March 1973. p. 177. 